\title{
A Field Guide for Well Site Geologists: Cable Tool Drilling
}

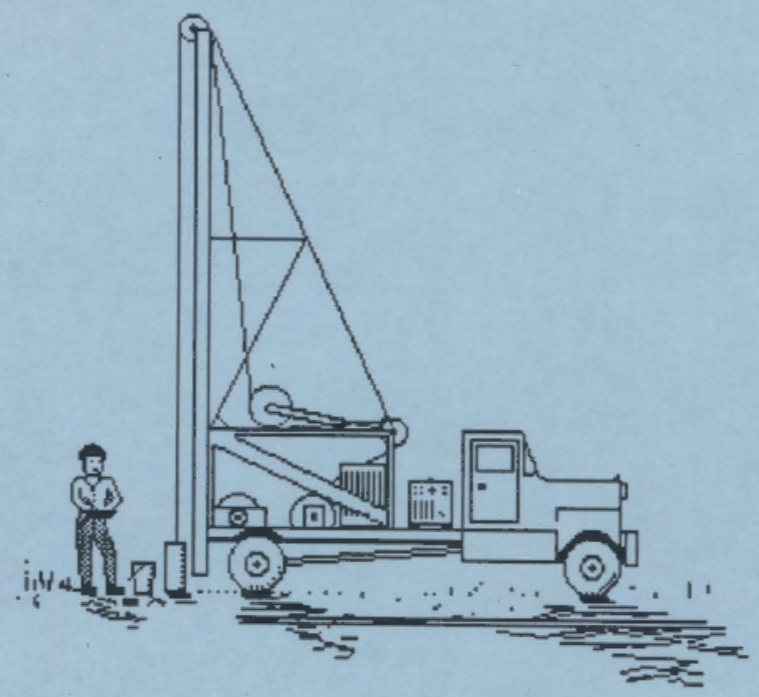

G. V. Last

T. L. Liikala

December 1987

Prepared for

the U.S. Department of Energy

under Contract DE-AC06-76RLO 1830

Pacific Northwest Laboratory

Operated for the U.S. Department of Energy

by Battelle Memorial Institute 


\title{
DISCLAIMER
}

This report was prepared as an account of work sponsored by an agency of the United States Government. Neither the United States Government nor any agency thereof, nor Battelle Memorial Institute, nor any of their employees, makes any warranty, expressed or implied, or assumes any legal liability or responsibility for the accuracy, completeness, or usefulness of any information, apparatus, product, or process disclosed, or represents that its use would not infringe privately owned rights. Reference herein to any specific commercial product, process, or service by trade name, trademark, manufacturer, or otherwise, does not necessarily constitute or imply its endorsement, recommendation, or favoring by the United States Government of any agency thereof, or Battelle Memorial Institute. The views and opinions of authors expressed herein do not necessarly state or reflect those of the United States Government or any agency thereof, or Battelle Memorial Institute.

\author{
PACIFIC NORTHWEST LABORATORY \\ operated by \\ BATTELLE MEMORIAL INSTITUTE \\ for the \\ UNITED STATES DEPARTMENT OF ENERGY \\ under Contract DE-AC06-76RLO 1830
}

\author{
Printed in the United States of America \\ Available from \\ National Technical Information Service \\ United States Department of Commerce \\ 5285 Port Royal Road \\ Springfield, Virginia 22161 \\ NTIS Price Codes \\ Microfiche A01
}

Printed Copy

$\begin{array}{lr}\text { Pages } & \begin{array}{r}\text { Price } \\ \text { Codes }\end{array} \\ 001-025 & \text { A02 } \\ 026-050 & \text { A03 } \\ 051-075 & \text { A04 } \\ 076-100 & \text { A05 } \\ 101-125 & \text { A06 } \\ 126-150 & \text { A07 } \\ 151-175 & \text { A06 } \\ 176-200 & \text { A09 } \\ 201-225 & \text { A010 } \\ 226-250 & \text { A011 } \\ 251-275 & \text { A012 } \\ 276-300 & \text { A013 }\end{array}$


PNL-6392

UC-70

\title{
A FIELD GUIDE FOR WELL SITE GEOLOGISTS: CABLE TOOL DRILLING
}

\author{
G. V. Last \\ T. L. Liikala
}

December 1987

Prepared for the U.S. Department of Energy under Contract DE-AC06-76RLO 1830

Pacific Northwest Laboratory Richland, Washington 99352 



\section{PREFACE}

This field guide is intended for use by Pacific Northwest Laboratory well site geologists who are responsible for data collection during the drilling and construction of monitoring wells on the Hanford Site. This guide presents standardized methods for geologic sample collection and description, and well construction documentation. 



\section{CONTENTS}

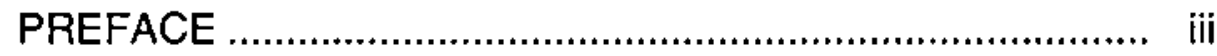

INTRODUCTION ............................................................... 1

GENERAL PROTOCOL …....................................................

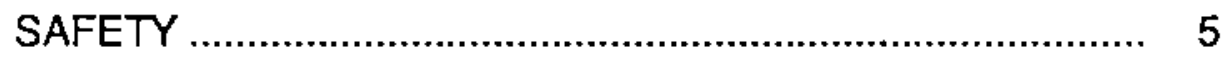

PREDRILLING ACTIVITIES ............................................ 7

ACQUISITION OF EQUIPMENT AND MATERIALS.... 7

Equipment for Each Geologist ......................... 7

Equipment for Each Drill Rig ......................... 7

Equipment for Each Study Area ...................... 7

PREPLANNING OF DAY'S ACTIVITIES ................... 7

Geophysical Logging or Hydrologic Testing ...... 7

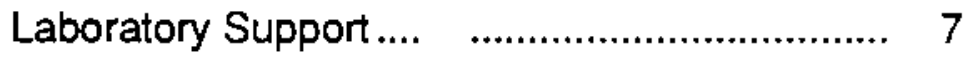

Senior Technical Reviewer ............................... 7

DOCUMENTATION, COLLECTION, AND DESCRIPTION

OF SAMPLES; WELL CONSTRUCTION DATA .................... 9

APPLICABLE FORMS ….................................... 9

COLLECTION OF SAMPLES ................................. 9

Sample Collection ....................................... 9

Moisture Samples ........................................... 10

Lithologic Samples ....................................... 10

Unusual Samples ........................................ 10 
Labeling ........................................................ 11

Leftover Sediment ........................................ 11

DESCRIPTION OF SAMPLES AND WELL

CONSTRUCTION DATA …....................................... 11

Sample Description ...................................... 11

Well Construction Data ................................. 19

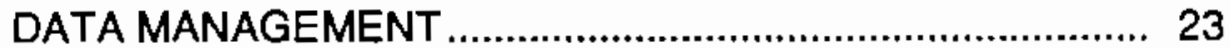

COPIES OF DRILL LOGS ..................................... 23

DISPERSION OF ORIGINALS ................................ 23

STORAGE OF UNCONTAMINATED SAMPLES ......... 23

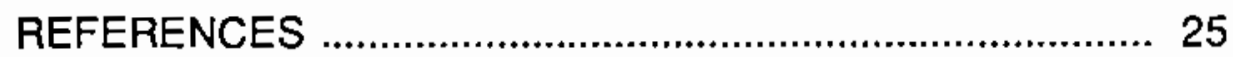

APPENDIX A - LITHOLOGIC AND WELL COMPLETION

SYMBOLS FOR THE AS-BUILT DIAGRAM.. A.1

APPENDIX B - PROCEDURE FOR COLLECTION AND DOCUMENTATION OF DRIL_.ING DATA P-6 FOR RCRA COMPLIANCE/HAZARDOUS MATERIALS MONITORING B.1 


\section{FIGURES}

1 Ternary Diagram for Naming of Sediments ................ 13

2 Enlarged Photocopy of Geologist's Grain-Size Chart .. 14

3 Charts for Visually Estimating Percentage Composition of Sediments .......................................................... 15

$4 \quad$ Terms for Degrees of Sorting .................................... 17

5 Terms for Degree of Roundness of Sediment Grains as Seen with Hand Lens ......................................... 18

A.1 Lithologic Symbols to be Used for the As-Built

Diagram

A. 1

A.2 Well Completion Symbols to be Used for the As-Built Diagram ....

\section{TABLES}

1 Sediment, Nomenclature, Sieve Sizes, and Well-Screen Slot Sizes

2 Estimation of Artificial Sand Pack and Screen

Slot Sizes 


\section{INTRODUCTION}

The Pacific Northwest Laboratory (PNL), under contract to the U.S. Department of Energy, is responsible for hydrogeologic data collection and well construction documentation associated with the installation of numerous monitoring wells on the Hanford Site. Currently, a large number of these wells are being drilled to bring hazardous waste sites into compliance with the Resource Conservation and Recovery Act (RCRA). This etfort requires the support of numerous well site geologists to document the geohydrologic conditions and well construction of each monitoring well. Our principal objective is to obtain this information in a consistent and technically sound fashion. The PNL technical procedure for collection and documentation of drilling data (Appendix $B$ ) defines the required data collection and documentation procedures to be followed by the well site geologists.

This field guide was prepared to give detailed information and examples about the collection and documentation of well site data. 


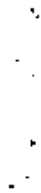




\section{GENERAL PROTOCOL}

Use the Procedure for Collection and Documentation of Drilling Data P-6 for RCRA Compliance/Hazardous Materials Monitoring (Appen$\operatorname{dix} B$ ), and follow the site-specific well construction specifications.

Check with the lead geologist at the site for guidance concerning technical questions, unusual occurrences, or trouble shooting. If the lead geologist is unsure of how to proceed, then one of the field troubleshooters should be notified. If a telephone is not available, radio Station 14 for assistance and stand by. If there is a contamination problem, do not discuss this directly over the radio unless absolutely necessary; use a telephone. The field trouble-shooters will submit any serious technical completion problems to the Technical Forum for resolution. The lead geologists, field trouble-shooters, and Technical Forum personnel are designed by each project manager. 



\section{SAFETY}

Safety Plans - be familiar with and adhere to the site-specific health and safety plans.

Welding - don't look at the arc without proper eye protection.

Heavy Objects - wear steel-toed boots and stay clear of the drill ing whenever possible. All drilling tools are heavy. When lifting heavy objects, use your legs, not your back. It is best, however, to let the drillers do the lifting.

Moving Machinery - keep hands and loose fitting clothes away from rotating parts. Stay at least $50 \mathrm{ft}$ away from the drill rig when casing is being pulled back.

Natural Hazards (i.e., wind, lightning, and rain) - stay away from the rig. Stop work at the driller's discretion. Use common sense.

Heat Exhaustion/Heat Stroke - get out of the heat and cool the body down by applying cold packs or a wet cloth. Drink lots of water.

Potential Contamination - be conscientious around potential contaminants. Wear coveralls and gloves; leave field clothes at work. Be sure Radiation Protection Technologists (RPTs) and other safety personnel conduct surveys regularly during the day and before going home. If contamination is detected, stop work until proper procedures are established.

Safety Equipment - wear hard hat, gloves, boots, safety glasses, and ear plugs.

Radio Communications - call Station 14 or the $100-\mathrm{N}$ control room (emergency only). 



\section{PREDRILLING ACTIVITIES}

\section{Acquisition \\ of Equip- \\ ment and \\ Materials \\ Equipment For \\ Each Geolo- \\ gist}

Equipment For

Each Drilling

Rig

Equipment For

Each Study

Area

\section{Preplanning \\ of Day's \\ Activities}

Geophysical

Logging or

Hydrologic

Testing

Laboratory

Support

(physical

analyses)

Senior Techni-

cal Reviewer
Coordinate with Field Equipment/Materials Specialist

Hard hat, safety boots, ear plugs, safety glasses, leather gloves, rubber gloves, two-way radio, water, and lunch.

Geologist kit, sample labels, sharpies, pencils, moisture tins, plastic bags, white tape, duct tape, sample jars, three 5-gal buckets, water, clipboard, drilling forms (Well Completion/Title III Inspection, As-built Diagram, Drill Logs), Procedure P-6, Well Specifications, E-tape, steel tape, blue chalk, engineer's tape, and soap stone.

Tongs, aluminum foil, laundry (coveralls, towels, rags), mud balance, and $\mathrm{HNU}$ photo-ionizer (HNU Systems, Inc.) (for volatile organics).

Plan ahead and let appropriate people know approximately when they will be needed on site; give them a definite time after it has been determined.

Let the soils laboratory supervisor know when samples will be coming in, where they will stored, what analyses are to be performed, and when the analyses should be completed.

Let the senior technical reviewer know about the previous day's problems/progress and the current day's planned activities. 


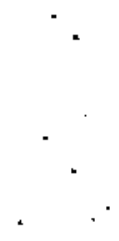




\section{DOCUMENTATION, COLLECTION, AND DESCRIP- TION OF SAMPLES; WELL CONSTRUCTION DATA}

\section{Applicable Forms}

Collection of Samples

Sample Collection
Well Completion Report/Title III Inspection List (See Appendix B, Attachment 1) - one per well; include general project and well information, drilling method, completion data, casing data, perforations, screen, annular seal, geophysical logging, and aquifer testing. Make sure this report is updated at the end of each shift.

As-Built Diagram (See Appendix B, Attachment 2) - one per well unless otherwise needed; include well number, geologist, page number, construction data, depth in feet, geologic, and hydrologic data. Use the symbols in Appendix A to update this diagram at the end of each shift.

Drill Log (See Appendix B, Attachment 3) - at least one per day; include geologist's name, date, ing [model and number, e.g., Bucyrus Erie 22W (ONWEGO No. 2)], well number, depth at start of page, depth at finish of page, computer number, project number, subcontract number, total casing, depth, drill method, wet/dry sample, lithologic description (including moisture sample data), time (24-hr clock), drilling comments, and remarks. Use a new log sheet each day. Sign and date it at the end of each day.

NOTE: The documentation associated with each well will be periodically reviewed by the senior technical reviewer.

Have drillers collect samples at 5-ft-depth intervals and at significant changes in lithology. Drive barrel sampling should be used where ever possible above the water table.

Drive barrel - have the driller knock out samples from the very end of the drive barrel into a clean, 
5 -gal bucket. Note the amount of open hole when sampled, if water was added, or if the sample was dropped (i.e., anything that might affect the sample's representativeness).

Hard tool - have the driller dump samples out of the bailer into a clean, 5-gal bucket. Note whether a dart bailer or flat-bottom bailer was used; this will indicate how representative the sample is.

Moisture Samples

Lithologic Samples

Unusual Samples
Collect a moisture sample from the 5-gal bucket immediately after each drive barrel sample is obtained from the driller. Put each sample in a moisture tin, seal the tin with white tape, label it, and double bag it using a plastic bag and tape. At the end of each shift, place each moisture sample in the refrigerator in the back room of the Sigma V building.

Collect two pint jar samples from the 5-gal bucket. Try to get representative samples by collecting from a vertical column within the bucket or by rolling and tumbling the bucket before sample collection. If you are busy, write the depth on the outside of the bucket or leave the labeled moisture sample in the bucket until you can get back to it.

Split-tube Core Barrel (split-spoon) - note depths where the driller started and stopped driving the sampler. After disassembly of the sampler, immediately wrap plastic bags around the sleeved core, taping the ends closed. Use the material retained in the drive shoe for the description. Place the core in the refrigerator at the end of the shift. This method is used to recover relatively undisturbed samples.

Wood (for $\mathrm{C}^{14}$ ) - use tongs to pick up the wood fragments, then wrap them in aluminum foil; store in refrigerator.

Basalt (for X-ray Diffraction) - pick out only the best (clean and pure) basalt chips; need approximately $15 \mathrm{~g}$ (7-dram vial). 
Labeling

Leftover Sediment

\section{Description \\ of Samples \\ and Well \\ Construction \\ Data}

Sample Description
Label each sample directly on the jar lid and on a sample label on the side of the jar. The following information should be included: well number, depth, date, drilling method, and geologist's initials. Moisture samples should be labeled on a piece of white tape wrapped around the side of the moisture tin. Store samples in the cardboard boxes that the sample jars came in. When a box is full, it should be sealed with duct tape and labeled with the well number and depth range. Protect hard tool samples from freezing during cold weather.

Use the remaining sample in the 5-gal bucket for sediment description.

Conscientiously observe all the drill cuttings as they are removed from the borehole. Talk to the driller about changes in the drilling conditions and/ or changes in the appearance of drill cuttings. If a major change is noted in the drilling conditions or physical appearance of the material, ask the driller to collect a sample of the new material. If the change is not significant, record a brief description of the changes based on observation of the drill cuttings.

When a sample is collected, use the portion of sample left in the 5-gal bucket (after collection of moisture and jar samples) for your descriptions. Include a description of clasts too large to fit in the sample jars; note the maximum clast size. Note if the sediment left in the bucket is different than the sediment collected in the jars. If the sample is hard tool, you may want to wash or wet sieve it (using 2-rm sieve and pan) before writing a 
description. Include the following items in your descriptions making sure the information is recorded in the appropriate columns on the Drill Log form:

1. Depth - for example, 4-5' (measurement should be in feet)

2. Drill method - $\mathrm{H}$ (hard tool), $\mathrm{D}$ (drive barrel), B (back-hoe), ST (split tube)

3. Wet/Dry Sample - D (dry), SM (slightly moist), $M$ (moist), VM (very moist), $W$ (wet)

4. Lithologic Description - includes the following:

- Sample Name - for example, SANDY GRAVEL. This name should be based on its texture and derived from the ternary diagram in Figures 1 and 2.

- Texture - for example, $15 \%$ FP (fine pebble), $30 \%$ VFP (very fine pebble), $30 \%$ VCS (very coarse sand), $15 \%$ CS (coarse sand), and $10 \% M$ (silt). Estimate the volume percent of each grain size starting with the coarsest fraction first. Use the grain-size charts in your geologist kit (Figure 2) and the visual percent charts (Figure 3).

The percentage of fine (silt and clay) can be estimated by placing a small portion of the sample $(\sim 50 \mathrm{~g})$ into a glass pint jar, which is approximately three quarters full of water, and mix thoroughly. After the sediment has settled out, the percentages of silt and clay can be estimated by examining the thicknesses of the various layers in the jar. Clay will take a long time to settle but can be estimated by the opaqueness of the water covering the sediments. Clay can 


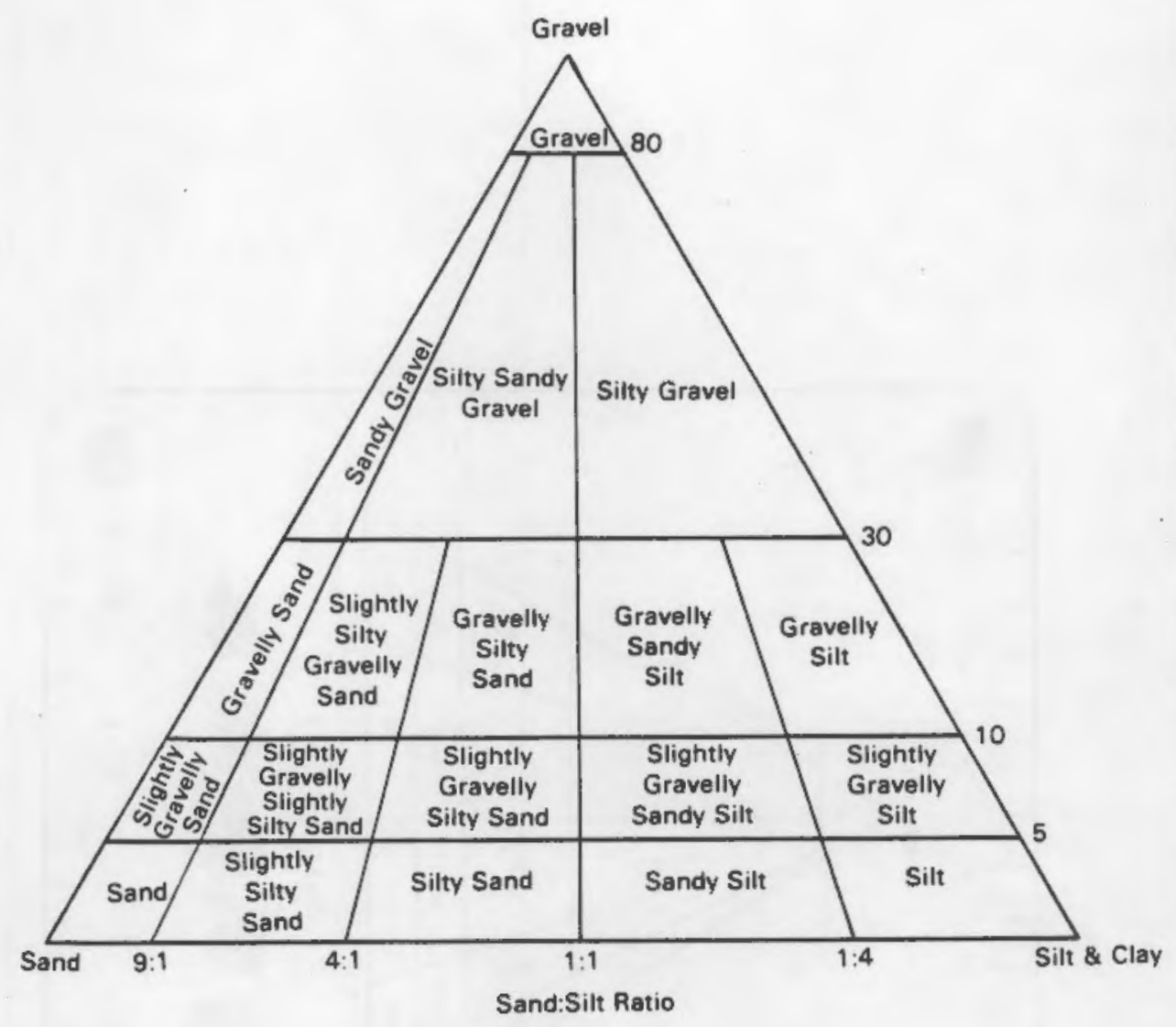

FIGURE 1. Ternary Diagram for Naming of Sediments (modified after R. L. Folk 1968, taken from Taliman et al. 1979)

also be distinguished from silt by its greasy or sticky feel and its cohesive properties (i.e., its ability to stay in clumps or adhere to clasts).

- Sorting - use the terms: very well sorted, well sorted, moderately sorted, poorly sorted, and very poorly sorted. The degree of sorting is determined by estimating the lower size limit of the coarsest $10 \%$ of the detrital grains and the upper size limit of the finest $10 \%$. These limits are then compared with the size scale to determine the 


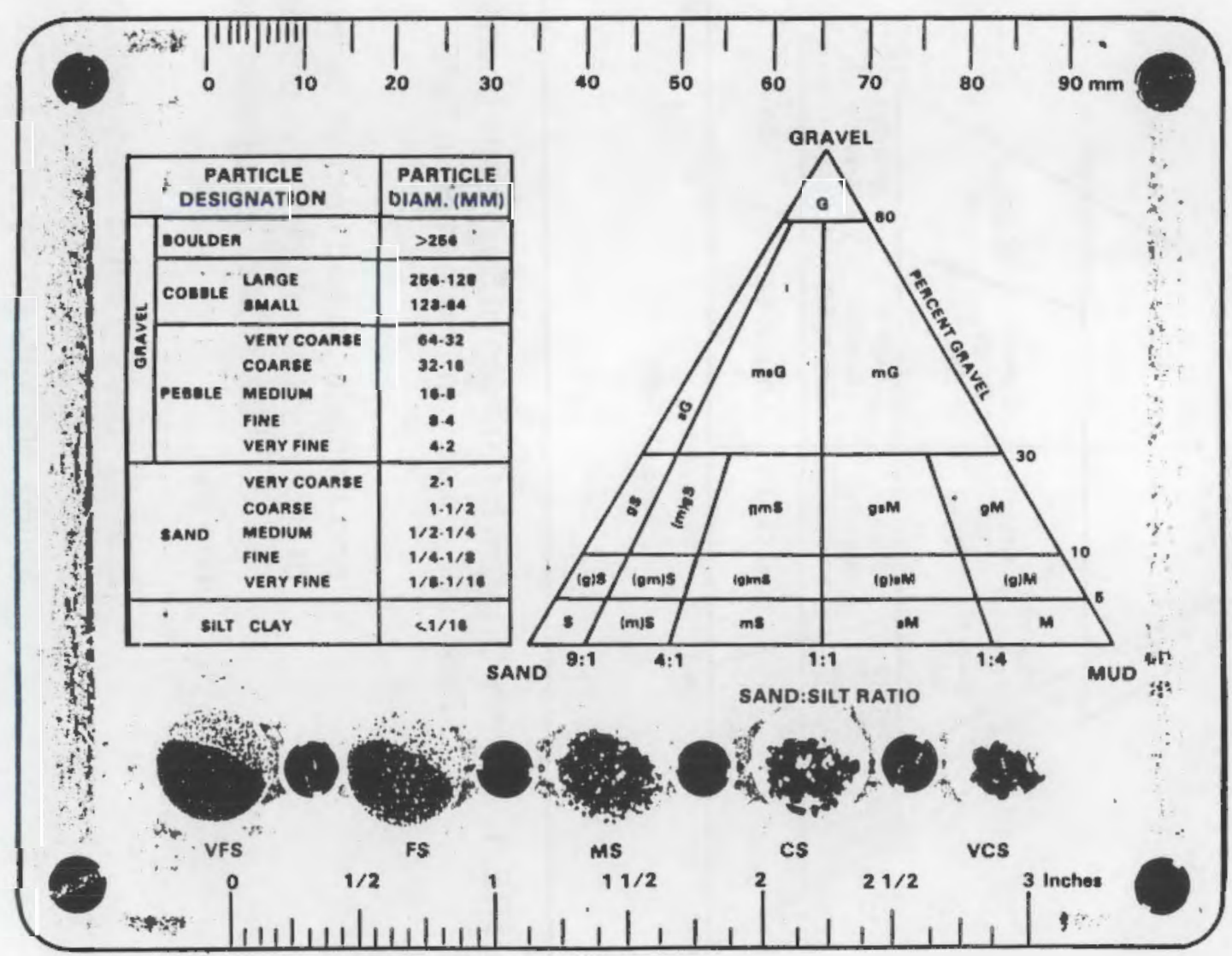

FIGURE 2. Enlarged Photocopy of Geologist's Grain-Size Chart. (Note that the ternary diagram uses symbols for the sediment classes, these symbols correspond to the names in Figure 1.) 

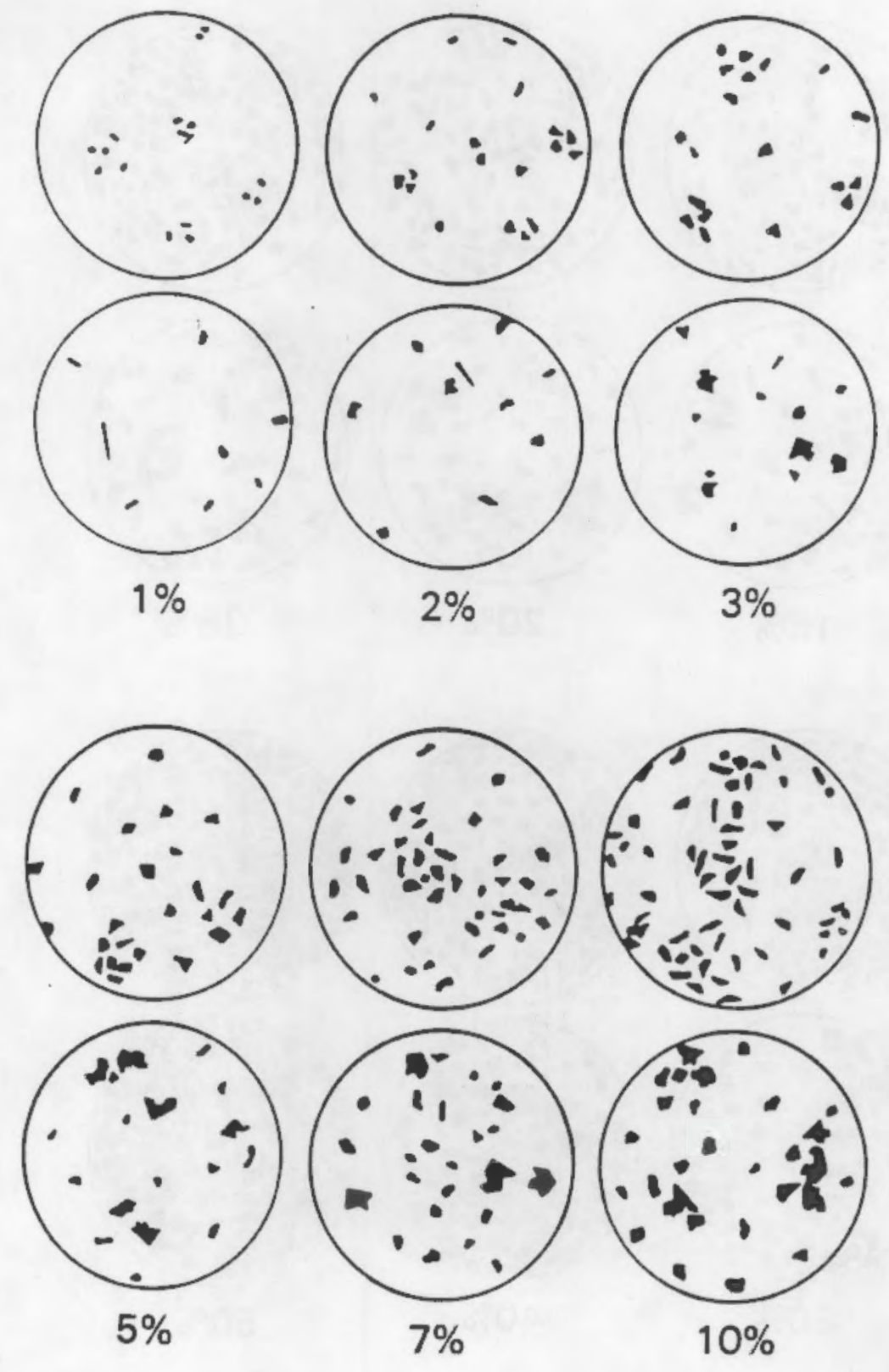

FIGURE 3. Charts for Visually Estimating Percentage Composition of Sediments (taken from Compton 1962) 


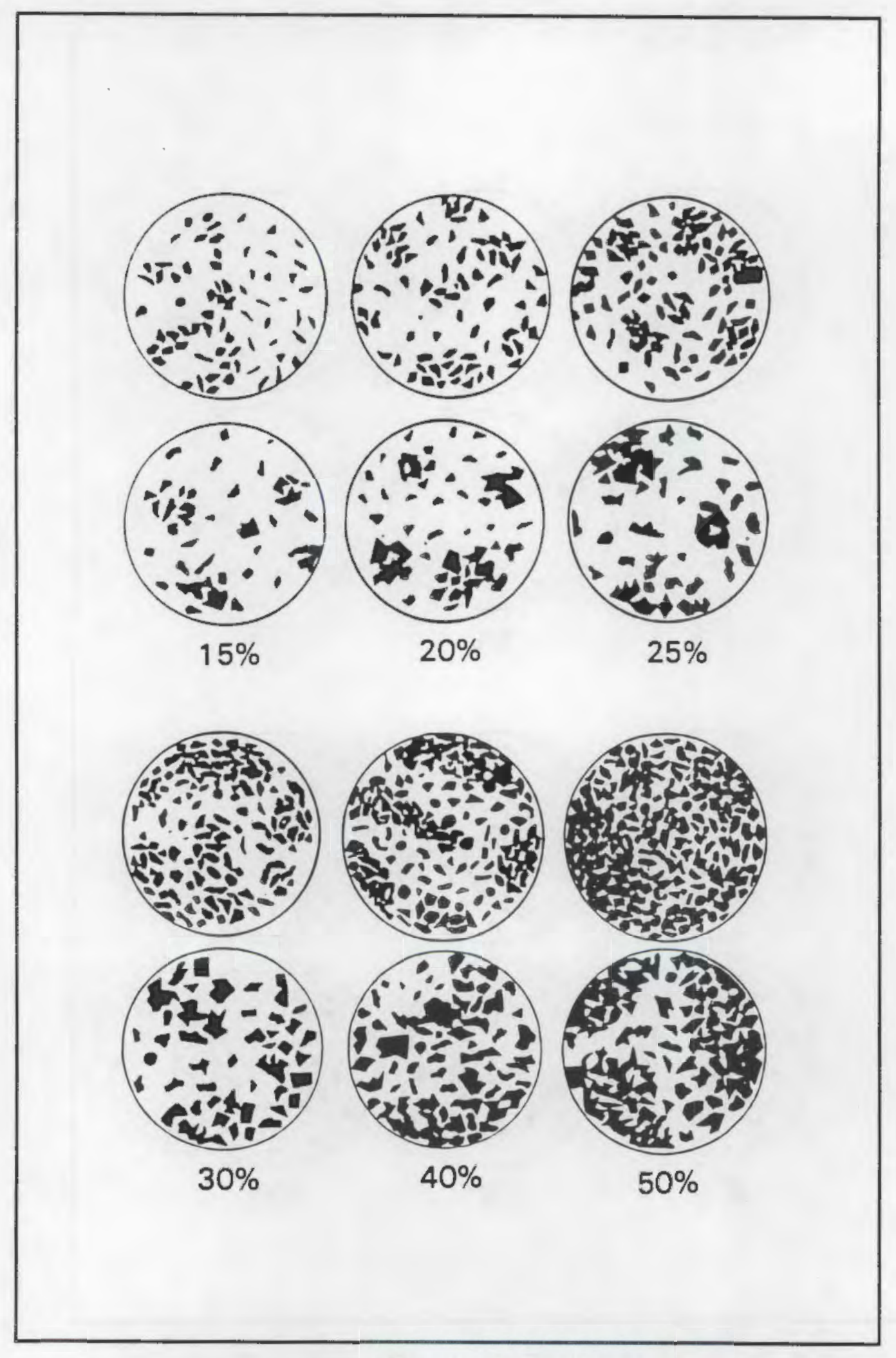

FIGURE 3. (contd) 


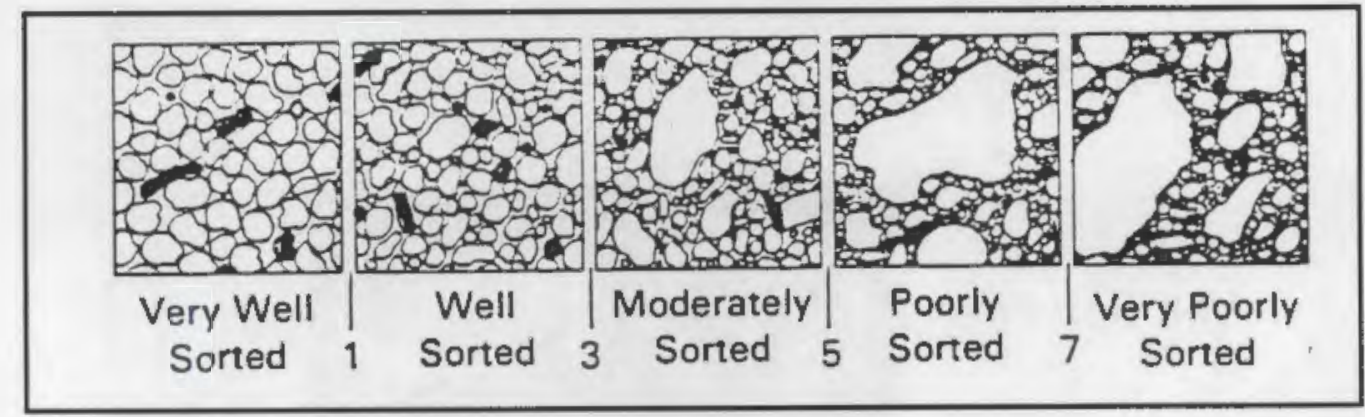

FIGURE 4. Terms for Degrees of Sorting. [The numbers indicate the number of size classes included by the great bulk $(80)$ of the material. The drawings represent sediments as seen with a hand lens. Taken from Compton 1962.]

number of size classes (very fine pebble, very coarse sand, coarse sand, etc.) between them. This number gives a measure of the degree of sorting (Figure 4).

- Gross Mineralogy - for example, gravels are $50 \%$ basalt, $30 \%$ quartzite, $10 \%$ diorite, and $10 \%$ other; sands are $40 \%$ basalt, $60 \%$ quartz and feldspar. Describe the gravel fraction first and then the sand fraction. Estimate the percent of basalt and other lithologies/mineralogy by using pebble counts or the visual percent charts (Figure 3).

- Roundness - use the terms: very angular, angular, subangular, subrounded, rounded, and well rounded. For example, gravel is rounded, and the sand is subrounded to angular. Again, describe the gravel fraction first then the sand fraction. Use the roundness charts (Figure 5).

- Wet/Dry Color - use the Munsel Color Charts (Munsell 1975) to delineate both the color name and numerical value of the fine portion of the sample. If the sample is hard tool, describe both the wet and dry color.

- Reaction to $10 \% \mathrm{HCl}$ - use the terms: no reaction, slight reaction, moderate reaction, 


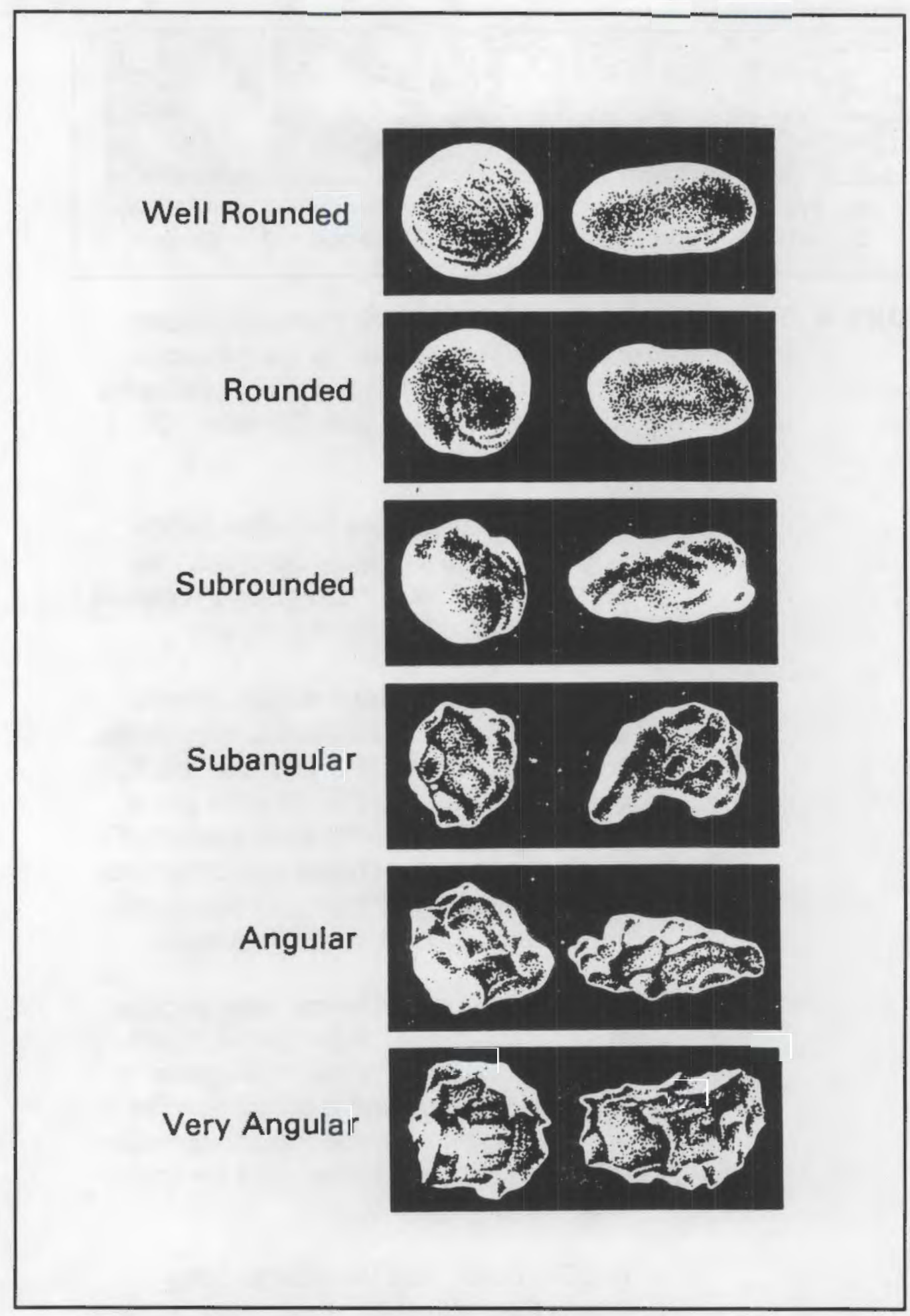

FIGURE 5. Terms for Degree of Roundness of Sediment Grains as Seen with a Hand Lens (taken from Compton 1962.) 
and strong reaction. Check the reaction on the dry, fine portion of the sample.

- Consolidation - use the terms:. unconsolidated, slightly consolidated, moderately consolidated, and well consolidated. Estimate the degree of consolidation from the drilling rate, driller's observations (e.g., hard or easy to drill, cemented or loose, stays open or collapses), and the presence of aggregates or cementation in the sample.

- Changes - note changes in texture, color, or lithologies (as compared to the last sample taken) and approximate depth where change occurred.

- Unusual Findings - for example, wood, smell, contamination, etc. Note the number and types of any special samples taken (moisture, wood, basalt, etc).

5. Time - use a 24-hr clock to note the time the driller collected the sample (e.g., 134; nr).

6. Drilling Comments - note drilling rate, if water was added, and any problems potentially influencing the sample's representativeness.

Well Construction Data

Record the following well construction data under the lithologic description column on the Drill Log form, unless stated otherwise.

1. Well Status - record (under "Drilling Comments" on the Drill Log) depth-to-water (D/ W) and depth-to-bottom (D/B) at the start of each shift. Note the times these measurements were taken in the time column. Use E-tape for D/W and steel tape for D/B. Measure to the nearest half foot and subtract the top of the casing so that depths are recorded in feet below land surface. 
2. Well Construction Activities - give a description of all construction activities including drill rig decontamination (e.g., steam cleaning), installation of casing (type, size, depth, and lengths - keep running totals in the Total Casing column), time, drill method, the type of tool lubricants used, drill depths, drill rates (covers time only while drilling and driving casing, does not include welding time, etc.), down time (maintenance work, stand by, etc.), amounts of drilling supply water used, initial depth-to-water, and geophysical logging activities.

\section{Selection of Well Completion Inter- val and Materials -}

- Select well-screen sizes using $50 \%$ pass through as a criterion where a natural sand pack is to be developed (sieve natural materials if questionable). Table 1 lists the sediment nomenclature and corresponding sieve and slot sizes.

- Using Table 2 as a general guide, estimate an artificial sand pack and associated screen slot sizes. If the proper selection is not obvious, then the lead geologist or field trouble-shooters should be contacted before the determination is made.

- Select the completion interval by using drilling specifications, geology, and geophysical logs.

- Note the selection and selection methods on the drill log. Check with the lead geologist if selections are not obvious and check with the field trouble-shooters or Technical Forum if problems are complex.

4. Well Completion Activities - record the completion depth, perforations (type, depth 
TABLE 1. Sediment, Nomenclature, Sieve Sizes, and Well-Screen Slot Sizes

Grain-Size

Nomenclature

(Wentworth

U.S. Standard

Sieve Opening

Well Screen

Grade Scale)

Sieve Mesh No.

$(\mathrm{mm} / \mathrm{in}$.)

Slot Size No.

Larger than

very fine

pebbles

\begin{tabular}{l}
$\begin{array}{l}\text { Very fine } \\
\text { pebbles }\end{array}$ \\
$\begin{array}{l}\text { Very coarse } \\
\text { sand }\end{array}$ \\
\hline Coarse sand
\end{tabular}

and schedule), screen (type, length, slot size, and depth), packer (type, size, and depth), sand or gravel pack (type, interval, and volume), and annular seal (type, inter$\mathrm{val}$, and volume). Take frequent $D / B$ measurements during installation of the sand pack and annular seals. Keep track of the $D / B$ versus the $D / B$ of the casing shoe and volumes of construction materials used per interval. Suggest that drillers not backfill too much at once. Use mud balance for checking grout or slurry. Once a specific Well Completion/Title 1II inspection item has been finished (i.e., screen set, sand 
TABLE 2. Estimation of Artificial Sand Pack and Screen Slot Sizes (Derived from Driscoll 1986)

Size Range of the Finest $30 \%$ of the Formation

Coarse silt to clay $(<0.063 \mathrm{~mm})$

Formation is uniform and $60 \%$ is fine sand to clay

Sand pack: 100 mesh

Screen slot size: 5

Very fine sand to clay (<0.125 mm)

Fine sand to to clay ( $<0.25 \mathrm{~mm})$
Sand pack: 20-40 mesh

Screen slot

size: 10

Sand pack:

16-30 mesh

20-30 mesh

10-20 mesh

Screen slot size:

20 with 16-30 or

20-30 me-h;

30 with $10-20$ mesh
Formation is highly nonuniform and contains silt and clay stringers

Sand pack: 20-40 mesh Screen slot size: 10

Sand pack: 16-30 mesh Screen slot size: 20

Sand pack: 8-12 mesh Screen slot size: 40

NOTE: For coarser sediments use 8-12 mesh sand and 40 slot screen.

pack placed, or seal placed), record under "Drilling Comments" the lower and upper interval depths and the total amount and type of material used.

5. Well Development and Hydrologic Testing Activities - record pertinent information (i.e., method, duration, discharge rate, drawdown, and total volumes extracted) during both well development and hydrologic testing activities. 


\section{DATA MANAGEMENT}

Copies of

Drill Logs

Dispersion of Originals

Storage of Uncontaminated Samples
Each night make a copy of the drill logs for 1) the driller, 2) the Kaiser drilling engineer, and 3) project files.

After completion of the project, the originals for each well shall be delivered to and retained by the geologic and geophysical records manager. Copies should be sent to the Geotechnical Engineering Unit in the Environmental Technology Section (Westinghouse Hanford Company).

Temporary storage (during data interpretation) will be in the shipping container behind Sigma $V$ or in the back room of Sigma $V$ during freezing weather.

Permanent storage will be in the sediment sample library in the 2101-M Building, 200 East. Fill out Sample Transfer record sheets and give to Information Services (Boeing Computer Services, Richland). 
. 


\section{REFERENCES}

Compton, R. R. 1962. Manual of Field Geology. John Wiley \& Sons, Inc., New York.

Driscoll, F. G. 1986. Ground Water and Wells. Johnson Division, St. Paul, Minnesota.

Munsell Color. 1975. Munsell Soil Color Charts. Macbeth, a division of Kollmorgen Co., Baltimore, Maryland.

R. L. Folk. 1968. Petrology of Sedimentary Rocks, University of Texas, Austin, Texas.

Tallman, A. M., K. R. Fecht, M. C. Marratt and G. V. Last. 1979. Geology of the Separation Areas Hanford Site. South-Central Washington. RHO-ST-23, Rockwell Hanford Operations, Richland, Washington. 


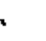

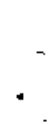




\section{APPENDIX A \\ LITHOLOGIC AND WELL COMPLETION SYMBOLS \\ FOR THE AS-BUILT DIAGRAM}




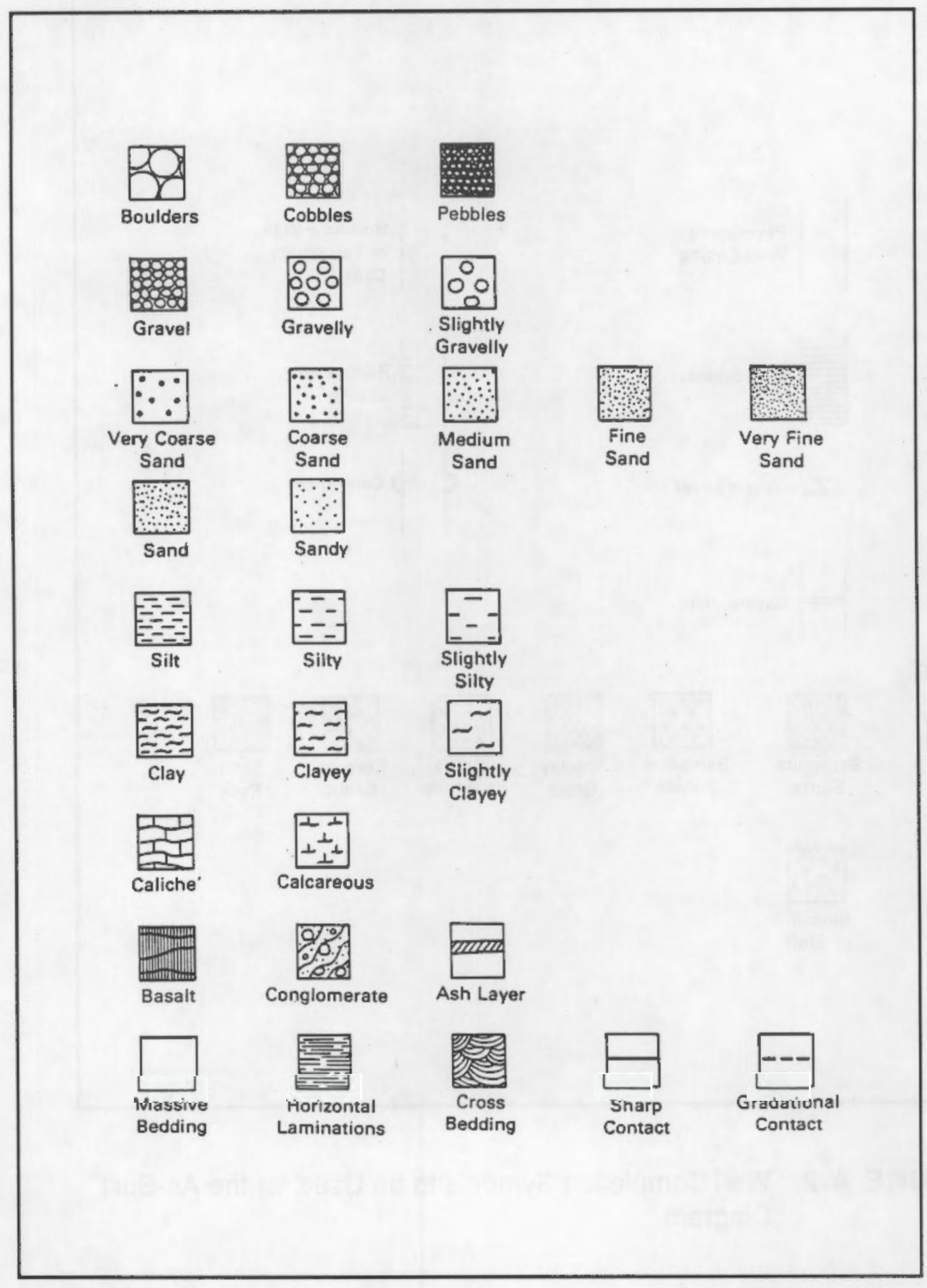

FIGURE A.1. Lithologic Symbols to be Used for the As-Built Diagram 


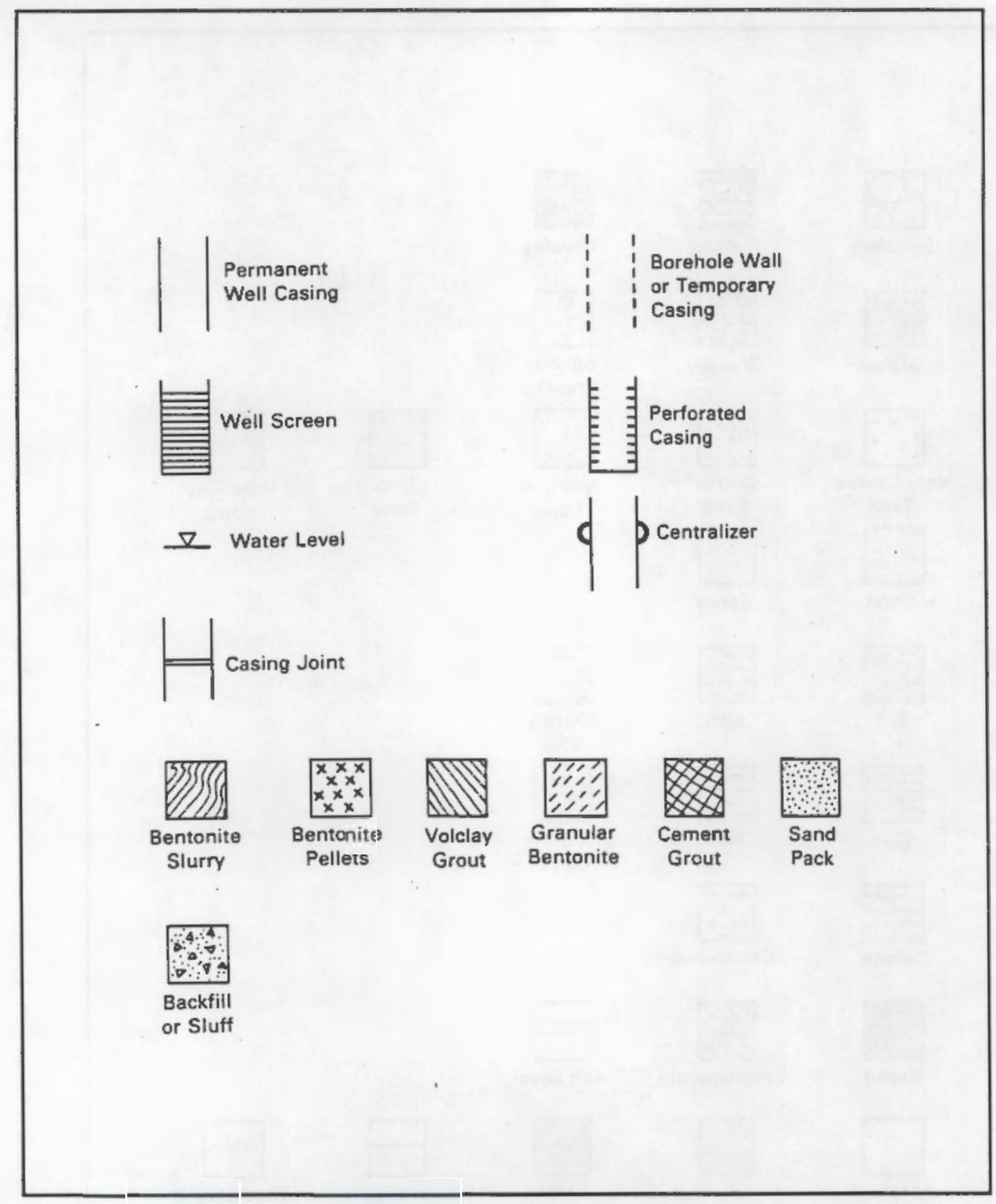

FIGURE A.2. Well Completion Symbols to be Used for the As-Built Diagram 


\section{APPENDIX B}

\section{PROCEDURE FOR COLLECTION AND DOCUMENTATION OF DRILLING DATA P-6 FOR RCRA COMPLIANCE/ HAZARDOUS MATERIALS MONITORING}




\section{Procedure for Collection and Documentation of Drilling Data P-6 for RCRA Compliance/Hazardous Materials Monitoring}

\subsection{OBJECTIVE}

This procedure provides standardized methods for the collection and documentation of sediment samples and well construction data, for wells drilled by the cable tool method.

\subsection{APPLICABILITY}

This procedure applies to work performed by well site geologists during well construction.

\subsection{RESPONSIBILITIES}

3.1 Well Site Geologist

- Collect and document drilling data

3.2 Senior Technical Reviewer

- Review and sign/date Well Completion Report/

Title III Inspection List

- Review and sign/date As-Built Diagram

- Review and sign/date Drill Logs

\subsection{PROCEDURE}

\subsection{Collection of Sediment Samples}

Sediment samples shall be collected by the well site geologist at 5-ft intervals and changes in formation. All drill cuttings to be sampled shall be collected from the driller in a 5 gallon bucket.

\begin{tabular}{|l|l|l|l|}
\hline $\begin{array}{l}\text { Approvals: } \\
\text { Project Managey }\end{array}$ & QA Rep. OP \\
\hline $\begin{array}{l}\text { Procedure No: } \\
\text { P-6 }\end{array}$ & $\begin{array}{c}\text { Revision No: } \\
0\end{array}$ & $\begin{array}{c}\text { Date Issued: } \\
3-16-87\end{array}$ & Page 1 of 4 \\
\hline
\end{tabular}


Two pint jars shall then be filled from the bucket. One jar shall be submitted for laboratory analysis and the other retained for archiving.

A label indicating well number, depth, date, drilling method and initials of the geologist collecting the sample shall be placed on each sample jar. Well number, depth and date shall also be written on the lid of each jar.

If the well is being drilled with a drive barrel above the water table, a moisture sample shall also be collected from the bucket. Each moisture sample shall be sealed with white identification tape. The well number, depth, date, and initials of the geologist collecting the sample shall be recorded on the identification tape with indelible ink. Each moisture sample shall then be doubly wrapped in a plastic bag, and taped shut.

The remainder of the sample in the bucket shall be used for sediment sample description.

4.2 Documentation of Sediment Samples and Well Construction Data

Sediment sample descriptions and well construction data for each well shall be recorded on a Well Completion Report/Title III Inspection List (Attachment 1), As-Built Diagram (Attachment 2) and Drill Log (Attachment 3). These data shall be recorded daily by the well site geologist. Nonapplicable items shall be designated N/A.

The Well Completion Report/Title III Inspection List provides a complete summary of well construction and completion data. Data recorded on the Well Completion Report/Title III Inspection List shall include: general data, pertorations, screen, annular seal, geophysical logging,

\begin{tabular}{|c|c|c|c|}
\hline $\begin{array}{c}\text { Procedure No. } \\
\text { P-6 }\end{array}$ & $\begin{array}{c}\text { Revision No. } \\
0\end{array}$ & $\begin{array}{c}\text { ate Issued: } \\
3-16-87\end{array}$ & Page 2 of 4 \\
\hline
\end{tabular}


aquifer testing, and other applicable items. Casing data, perforations, screen, annular seal, geophysical logging, aquifer testing, and other applicable items shall be approved by the well site geologist. After completion of the well, an overall review of the Well Completion Report/ Title III Inspection List shall be performed by the Senior Technical Reviewer.

The As-Built Diagram is a graphical representation of the well construction, geologic, and hydrologic data. Data recorded on the As-Built Diagram shall include: well number, geologist, page number, construction data, depth in feet, geologic and hydrologic data. After completion of the well, an overall review of the As-Built Diagram shall be performed by the Senior Technical Reviewer.

The Drill Log contains detailed descriptions of the sediment samples and well construction data. Data recorded on the Drill Log shall include: geologist's name, rig, well number, depth at start, depth at finish, computer number, project number, subcontract number, total casing, depth, drill method, wet/dry sample, lithologic description including moisture sample data, time, drilling comments, and remarks. A new Drill Log shall be used each day. After completion of the day's activities, the well site geologist shall sign and date the Drill Log. After completio, if the well, an overall review of the Drill Logs shall be performed by the Senior Technical Reviewer.

\subsection{Description of Sediment Samples and Well Construction Data}

Detailed descriptions of the sediment samples and well construction data shall be recorded on the Drill Log under "Lithologic Description" by the well site geologist.

Sediment sample descriptions shall include the following information as a minimum: lithologic name, texture,

\begin{tabular}{|c|c|c|l|}
\hline $\begin{array}{c}\text { Procedure No. } \\
P-6\end{array}$ & $\begin{array}{c}\text { Revision No. } \\
0\end{array}$ & $\begin{array}{c}\text { Date Issued: } \\
3-16-87\end{array}$ & Page 3 of 4 \\
\hline
\end{tabular}


sorting, gross mineralogy of the framework and matrix, roundness of the framework and matrix, wet/day color, reaction in hydrochloric acid $(\mathrm{HCl})$, consolidation and changes in lithology.

Well construction data shall include the following information as applicable: drill method, drill depth, completion depth, drill rate, casing type, size, depth and lengths), perforations (type, depth and schedule), screen (type, length, slot size and depth), annular seal (type, interval and volume), packer (type, size and depth), well development, and depth to water.

\subsection{Data Management}

After completion of the project, the original Well Completion Report/Title III Inspection List, As-Built Diagram and Drill Logs for each well shall be retained by $V$. L. McGhan of the PNL Geosciences Department. A copy of each completed form shall be retained by the PNL Records Retention Center.

Procedure No. P-6
Revision No.

0
Date Issued: $\quad$ Page 4 of 4 


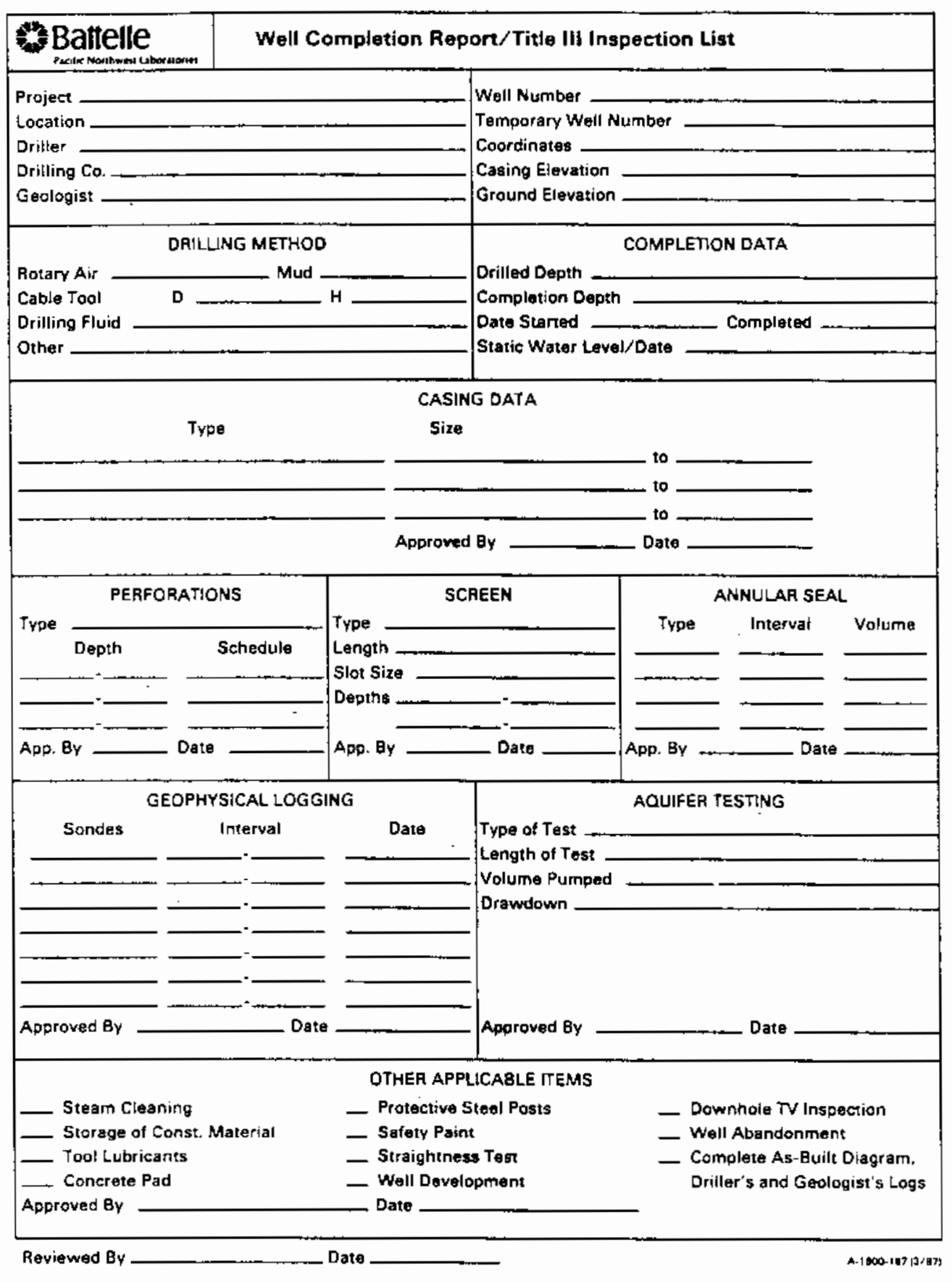

Procedure No. P-6, Rev. No. 0, Attachment 1, Page 1 of 1 


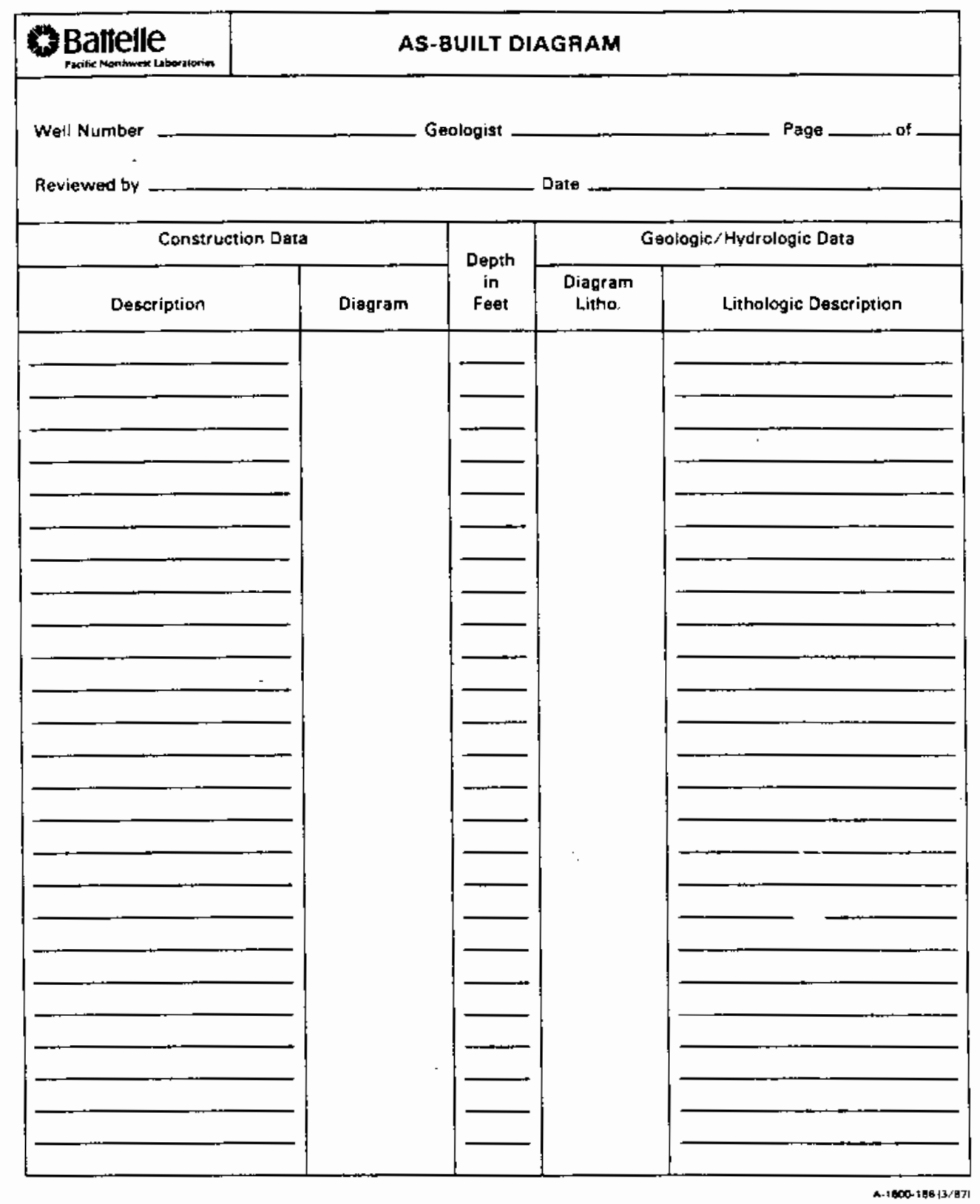

Procedure No. P-6, Rev. No. 0, Attachment 2, Page 1 of 1 


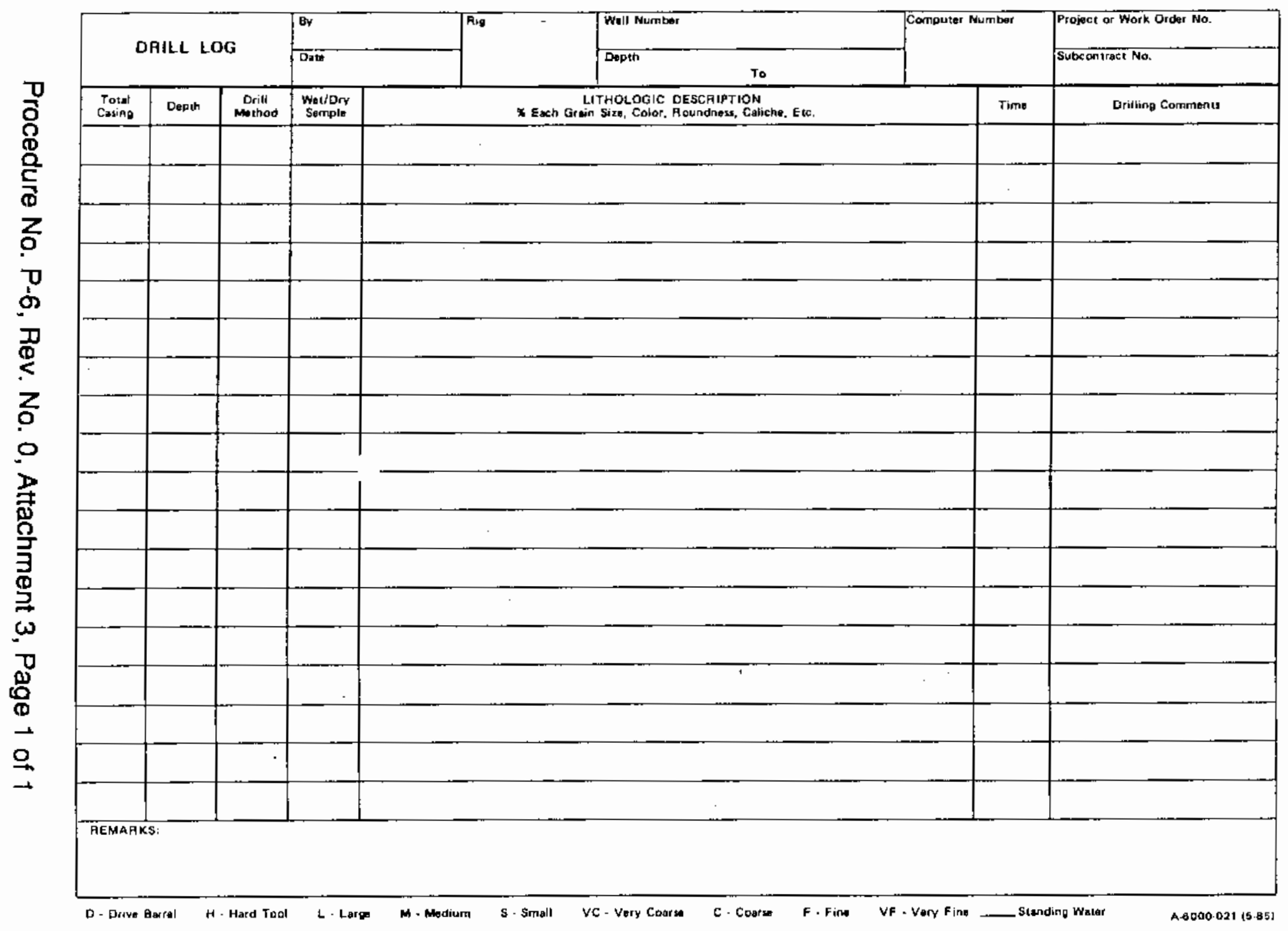



PNL-6392

\section{DISTRIBUTION}

No. of

Copies

OFFSITE

2 DOE Technical Information Center

\section{ONSITE}

5 DOE Richland Operations Office

M. J. Anthony

P. J. Krupin

M. W. Shupe

J. J. Sutey

M. W. Tiernan

8 Westinghouse Hanford Company

B. N. Bjornstad

T. S. Clawson

K. R. Fecht

R. B. Kasper

S. P. Luttrell

R. L. Premzic

D. C. Weekes

T. J. Woods
No. of

Copies

51 Pacific Northwest Laboratory

S. P. Airhart

M. A. Chamnes

C. S. Cline

D. W. Dragnich

M. D. Freshley

R. M. Fruland

T. J. Gilmore

S. M. Goodwin

J. M. Hales

P. C. Hays

E. J. Jensen

G. V. Last (15)

T. L. Liikala (10)

P. J. Mitchell

K. R. Oster

R. Schalla

R. M. Smith

A. L. Skaggs

J. A. Stottlemyre

M. E. Strong

S. S. Teel

J. S. Wilbur

R. E. Wildung

Publishing Coordination (2)

Technical Report Files (3) 
-

.

I 